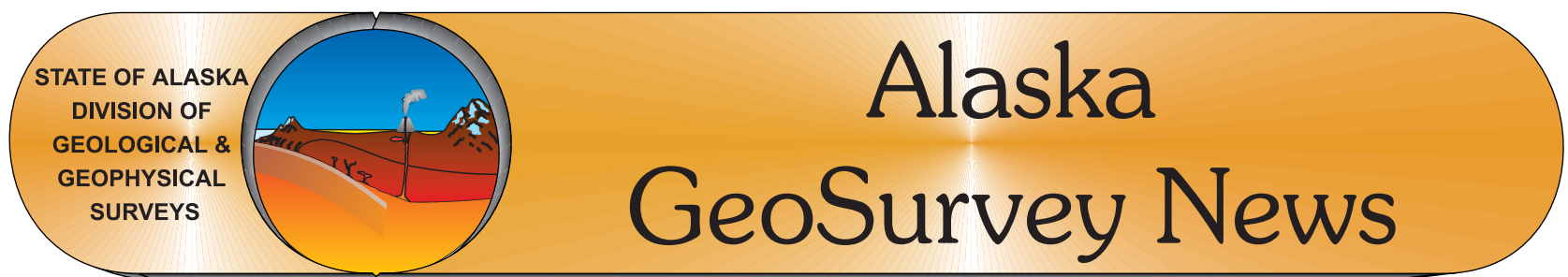

http://www.dggs.dnr.state.ak.us

Vol. 11, No. 1, March 2008

\title{
The Alaska Volcano Observatory - 20 years of volcano research, MONITORING, AND ERUPTION RESPONSE
}

Since 1988, the Alaska Volcano Observatory (AVO) has been monitoring volcanic activity across the state, conducting scientific research on volcanic processes, producing volcano-hazard assessments, and informing both the public and emergency managers of volcanic unrest. Below are some examples of the activity at Alaska's volcanoes that have held the attention of AVO staff.

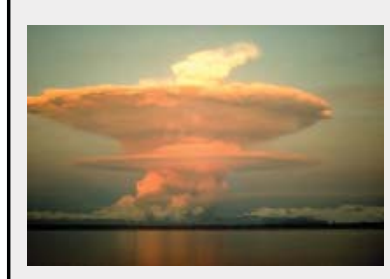

(a) 1989-90, Redoubt

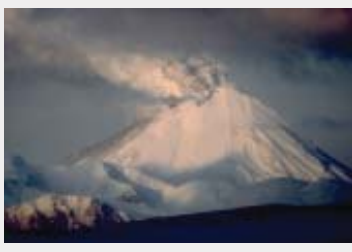

(f) 1994, Kanaga

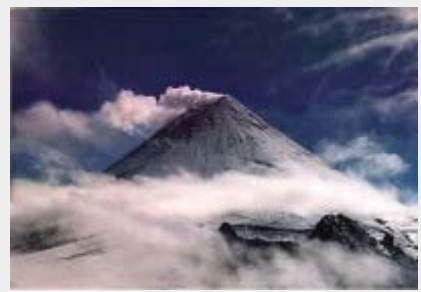

(k) 1999, Shishaldin

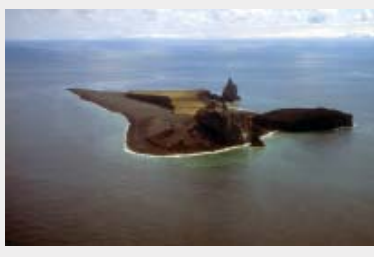

(b) 1992, Bogoslof

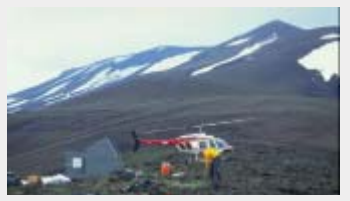

(g) 1996, Akutan

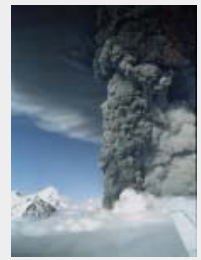

(c) 1992, Spurr

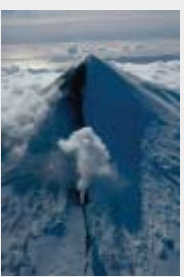

(h) 1996, Pavlof

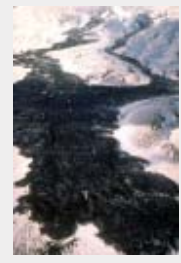

(d) 1992, Westdahl

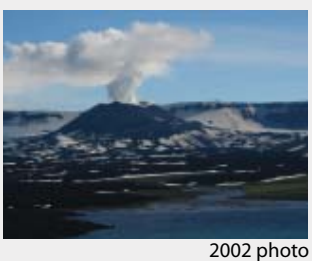

(i) 1997, Okmok

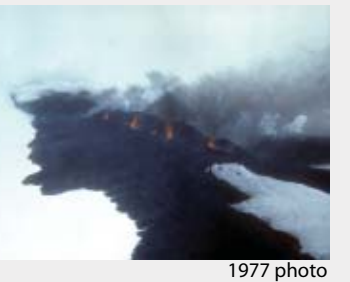

(e) 1993, Seguam

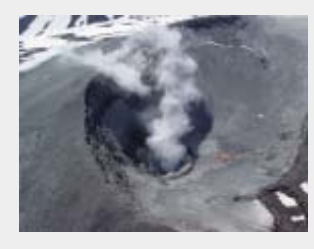

(j) 1998, Korovin

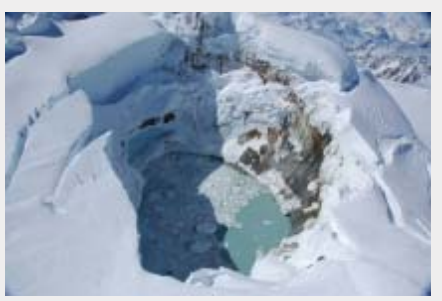

(I) 2004-06, Spurr

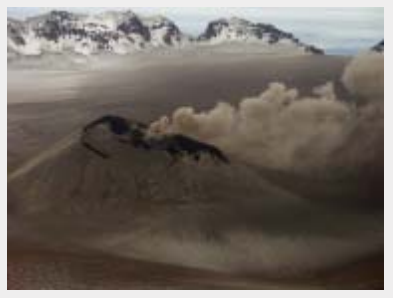

(m) 2005, Veniaminof

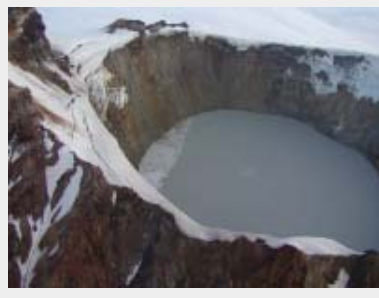

(n) 2005, Chiginagak

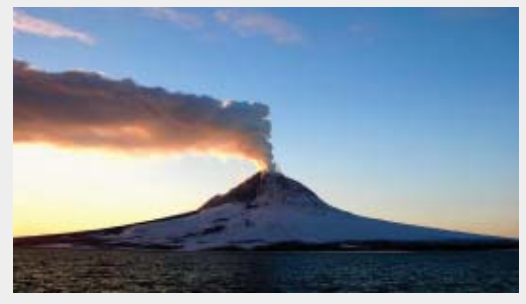

(o) 2006, Augustine

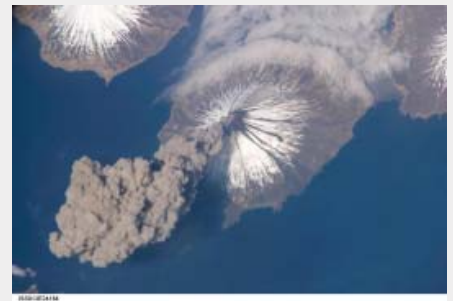

(p) 2006, Cleveland

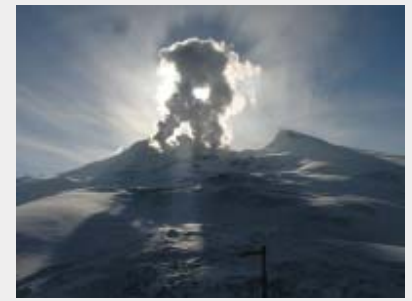

(q) 2006, Fourpeaked

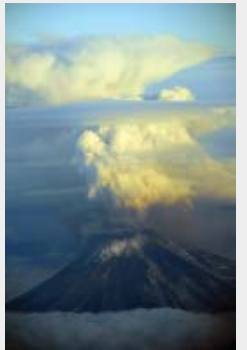

(r) 2007, Pavlof

Photo credits: (a) J. Warren, (b) T. Keith, USGS, (c) R. McGimsey, USGS, (d) C. Dau, USFWS, (e) U.S. Coast Guard (1977 photo), (f) E. Klett, USFWS, (g) R. McGimsey, USGS, (h) S. Schulmeister, (i) J. Freymueller, UAF/GI, (2002 photo), (j) R. McGimsey, USGS, (k) C. Nye, ADGGS, (l) D. Schneider, USGS, (m) K. Wallace, USGS, (n) J. Schaefer, ADGGS, (o) C. Read, USGS, (p) NASA, (q) K. Lawson, (r) C. Waythomas, USGS.

To see more photographs of Alaska volcanoes and learn more about these eruptions and others, visit the Alaska Volcano Observatory website at www.avo.alaska.edu. 


\title{
Monitoring the Active Volcanoes of Alaska
}

\author{
BY Janet Schaefer and Chris Nye
}

\section{INTRODUCTION}

Active volcanoes in Alaska? Yes! In fact, there are more than 50 historically active volcanoes in Alaska. Hardly a year goes by without a major eruption from a volcano in the Aleutian Arc.

Alaska's volcanoes are potentially hazardous to passenger and freight aircraft as jet engines sometimes stall after ingesting volcanic ash. On December 15, 1989, a Boeing 747 flying 240 kilometers (150 miles) northeast of Anchorage encountered an ash cloud erupted from Redoubt Volcano and lost power in all four jet engines. The plane, with 231 passengers aboard, lost more than 3,000 meters ( 9,800 feet) of elevation before the flight crew was able to restart the engines (Casadevall, 1994). After landing, it was determined the airplane had suffered about $\$ 80$ million in damage (Brantley, 1990).

We estimate that more than 80,000 large aircraft per year, and 30,000 people per day, are in the skies over and potentially downwind of Aleutian volcanoes, mostly on the heavily traveled great-circle routes between Europe, North America, and Asia. Volcanic eruptions from Cook Inlet volcanoes (Spurr, Redoubt, Iliamna, and Augustine) can have severe impacts, as these volcanoes are nearest to Anchorage, Alaska's largest population center.

The series of 1989-1990 eruptions from Mt. Redoubt were the second most costly in the history of the United States, and had significant impact on the aviation and oil industries, as well as the people of the Kenai Peninsula.

The three eruptions of Mt. Spurr's Crater Peak in 1992 deposited ash on Anchorage and surrounding communities, closed airports, made ground transportation difficult, and disrupted air traffic as far east as Cleveland, Ohio.

The 1912 Katmai eruption, which formed the Valley of Ten Thousand Smokes on the Alaska Peninsula, was the largest 20th-century eruption on earth.

Some quick facts and figures about the volcanoes in Alaska:

- Alaska contains in excess of 100 volcanoes and volcanic fields that have been active within the last 2 million years.

- More than 50 of these have been active in historic time (about the last 200 years).

- These volcanoes make up about $80 \%$ of all active volcanoes in the United States and $8 \%$ of all active above-water volcanoes on earth.

Most of Alaska's volcanoes are located along the 2,500kilometer-long (1,550-mile-long) Aleutian Arc, which extends westward to Kamchatka and forms the northern portion of the Pacific "ring of fire" (fig. 1, Monitoring status of active volcanoes in Alaska, pgs. 6-7). Other volcanoes that have been active in the last few thousand years exist in southeastern Alaska and in the Wrangell Mountains. Smaller volcanoes, some active within the last 10,000 years, are found in interior Alaska and in western Alaska as far north as the Seward Peninsula. Information on all of these volcanic centers can be found on the AVO website, www.avo.alaska.edu.

\section{The Alaska Volcano Observatory}

The volcanology section at the Alaska Division of Geological \& Geophysical Surveys (DGGS) works within the larger context of the Alaska Volcano Observatory (AVO), a joint program of the United States Geological Survey (USGS), the Geophysical Institute of the University of Alaska Fairbanks (UAF-GI), and DGGS. AVO was formed in 1988, and uses federal, state, and university resources to monitor and study Alaska's hazardous volcanoes, to predict and record eruptive activity, and to mitigate volcanic hazards to life and property. AVO has responded to more than 18 episodes of volcanic eruption or unrest since its inception.

AVO has three primary objectives:

- To conduct monitoring and other scientific investigations in order to assess the nature, timing, and likelihood of volcanic activity;

- To assess volcanic hazards associated with anticipated activity, including types of events, their effects, and areas at risk; and

- To provide timely and accurate information on volcanic hazards, and warnings of impending dangerous activity, to local, state, and federal officials and the public.

The three component agencies of AVO each bring particular strengths to the observatory, and at the same time share general expertise in volcanology (fig. 2). Among the agencies, DGGS has the clearest mandate for baseline geologic mapping and hazard studies. DGGS also has a remarkable degree of flexibility, which has allowed us to build and serve a large database of descriptive material about volcanoes and to build a cutting-edge system for intra-observatory communication and data sharing, providing notices of eruptions and unrest to users in public, private, and government sectors. Among volcano observatories worldwide, AVO has become the leader in information dissemination using powerful database and webbased tools. Particular strengths of the USGS are the federal hazards mandate and direct ties to federal agencies. UAF-GI brings a research mandate and access to resources (such as satellite data downlink centers) otherwise beyond the financial capability of AVO.

Alaska Division of Geological \& Geophysical Surveys, 3354 College Rd., Fairbanks Alaska 99709-3707

Emails: janet.schaefer@alaska.gov; cnye@giseis.alaska.edu 


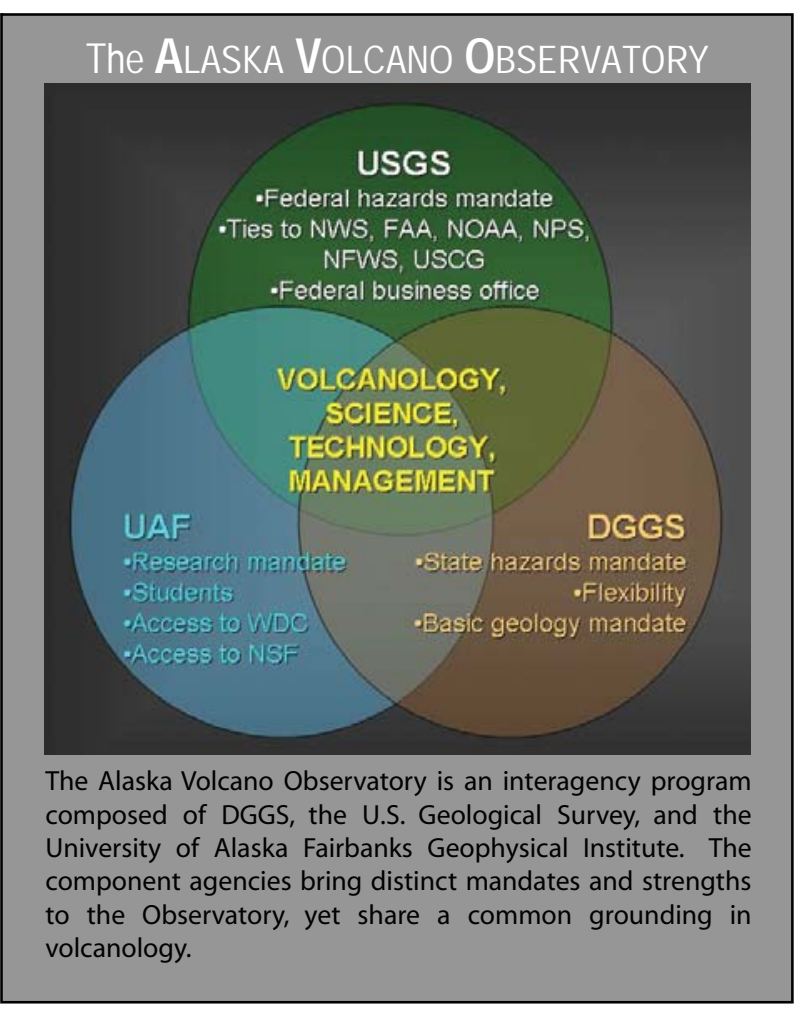

Figure 2. The three-agency organization of the Alaska Volcano Observatory.

\section{RECENT VOLCANIC UNREST PROVIDES AVO VOLCANOLO- GISTS WITH SCIENTIFIC OPPORTUNITY AND CHALLENGES}

Over the last three years (2005-2007), nine Alaska volcanoes were at an elevated level-of-concern color code (fig. 3): Martin, Spurr, Tanaga, Cleveland, Fourpeaked, Korovin, Veniaminof, Pavlof, and Augustine. Activity at these volcanoes ranged from phreatic explosions (Fourpeaked) and small ash emissions (Veniaminof) to lava flows and fire fountaining (Pavlof) to large ash clouds affecting air traffic (Cleveland and Augustine). The three events summarized below (the 2006 eruption of Augustine volcano, the 2006 eruption of Fourpeaked volcano, and the 2005 acid crater lake drainage at Chiginagak volcano) offer glimpses into the variety and complexity of work that the DGGS volcanology section geologists are involved in. The scientific data collected during these episodes of volcanic unrest continues to occupy scientists' time as they work to understand the volcanic processes that took place before, during, and after these events.

\section{The 2006 eruption of Augustine Volcano}

On January 11, 2006, Augustine volcano entered an explosive phase of eruption, sending ash to more than 9 kilometers (29,500 feet) above sea level (Power and others, 2006). The initial explosive phase was followed by lava effusion that continued through late March. In addition to the large ash clouds, the eruption generated pyroclastic flows, and a new lava dome whose steep sides occasionally failed, generating block and ash flows down the volcano's flanks. AVO staff stepped up to the task and were able to detect changes in earthquake activity and ground deformation that led to the raising of the color

\section{Volcano Alert Levels}

Normal

Volcano is in typical background, noneruptive state or, after a change from a higher level, volcanic activity has ceased and volcano has returned to noneruptive background state.

\section{Advisory}

Volcano is exhibiting signs of elevated unrest above known background level or, after a change from a higher level, volcanic activity has decreased significantly but continues to be closely monitored for possible renewed increase.

\section{Watch}

Volcano is exhibiting heightened or escalating unrest with increased potential of eruption, timeframe uncertain, $\mathbf{O R}$ eruption is underway but poses limited hazards.

\section{Warning}

Hazardous eruption is imminent, underway, or suspected.

\section{Aviation Color Codes}

\section{GREEN}

Volcano is in typical background, noneruptive state or, after a change from a higher level, volcanic activity has ceased and volcano has returned to noneruptive background state.

\section{YELLOW}

Volcano is exhibiting signs of elevated unrest above known background level or, after a change from a higher level, volcanic activity has decreased significantly but continues to be closely monitored for possible renewed increase.

\section{ORANGE}

Volcano is exhibiting heightened or escalating unrest with increased potential of eruption, timeframe uncertain, $\mathbf{O R}$ eruption is underway with no or minor volcanic-ash emissions [ash-plume height specified, if possible].

\section{RED}

Eruption is imminent with significant emission of volcanic ash into the atmosphere likely OR eruption is underway or suspected with significant emission of volcanic ash into the atmosphere [ash-plume height specified, if possible].

Figure 3. Ground hazard Alert Level and aviation Color Codes (Gardner and Guffanti, 2006). 
code from GREEN (volcano is dormant; normal seismicity and fumarolic activity) to YELLOW (volcano is restless; eruption may occur) on November 29, 2005, almost 2 months prior to the eruption.

Prior to the unrest detected in November 2005, the monitoring instrumentation at the volcano consisted of seven short period seismometers, one broadband seismometer, and six continuous GPS stations. As unrest continued, AVO began adding more monitoring instrumentation; by the end of the eruption, Augustine was the most well-monitored volcano in Alaska with five short-period seismometers, one strong motion seismometer, three temporary broadband seismometers, three EarthScope permanent continuous GPS stations, five temporary continuous GPS stations, three webcams, two time-lapse cameras, two radiometers, and one pressure sensor (figs. 4 and 5). The information received from these instruments allowed AVO to monitor significant changes at the volcano and to produce timely and accurate information releases regarding hazards at the volcano. In addition, the data acquired by these instruments

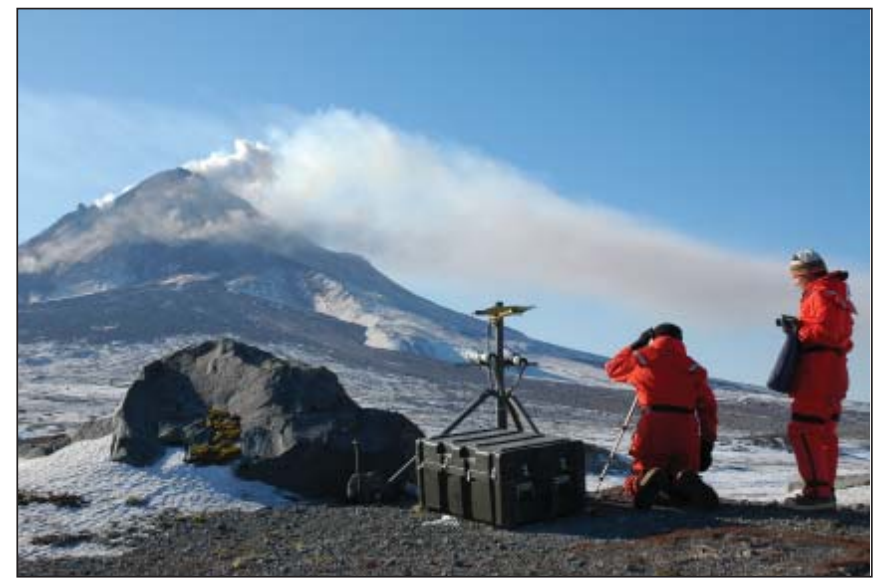

Figure 4. Radiometer at Burr Point on Augustine Island. AVO geologists use the radiometer and forward-looking infrared (FLIR) camera to measure temperatures of the summit dome, lava flows, and pyroclastic flows. Photo by T. Plucinski, March 15, 2006.

and subsequent site visits have provided AVO volcanologists with a wealth of information for the study of active volcanic processes such as precursory seismicity and ground deformation, pyroclastic and lava flow dynamics, lahars, dome growth, and ash and aerosol dispersion in the atmosphere.

AVO's response to the 2006 eruption of Augustine volcano serves as a flagship example of how current technological advances in instrumentation, data acquisition, and web-based communication, combined with a staff of experienced, knowledgeable volcanologists, can work together to provide both the public and emergency managers with accurate and timely information during hazardous volcanic events.

\section{A volcano awakens-the 2006 eruption of Fourpeaked volcano}

On September 17, 2006, Fourpeaked volcano, located at the northeastern end of the Alaska Peninsula, produced a plume of steam, ash, and $\mathrm{SO}_{2}\left(+\mathrm{CO}_{2}\right)$ gas that rose to 6,000 meters

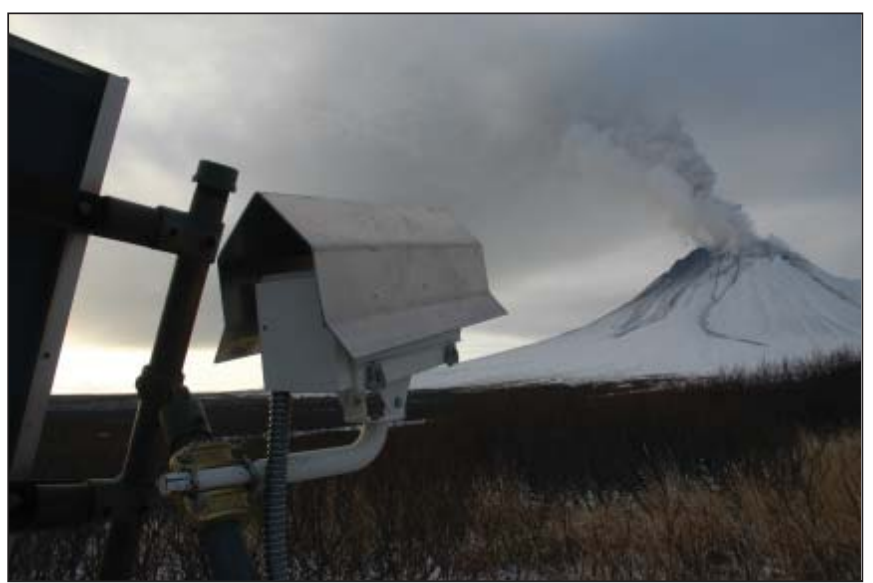

Figure 5. Webcam on Augustine Island. Images from the Augustine Island webcam were viewed more than 8 million times during January 2006. The camera also documented a spectacular pyroclastic flow on January 29, 2006. Photo by M. Coombs, January 12, 2006.

(20,000 feet) above sea level (fig. 6). The plume was observed by eyewitnesses and recorded by weather radar and $\mathrm{SO}_{2}$-sensitive satellite imagery. Air and ground reconnaissance by DGGS and USGS geologists revealed a linear series of vents in the summit glacier, stretching about 1 kilometer ( 0.6 mile) down the north flank of the volcano. The melting snow and ice produced a debris flow of hydrothermally altered volcanic rocks, clay, and sulfur, mixed with ice and boulders up to 5 meters (16 feet) in diameter.

The explosions at Fourpeaked volcano, a volcano with no known previous activity in the last 10,000 years, reminds us that volcanoes operate on a geologic time scale and that hazardous conditions can exist at volcanoes that have shown no activity in historic time. AVO continues to monitor activity at Fourpeaked with a webcam, intermittent gas flights, and a seismic network.

The 2005 catastrophic acid crater lake drainage, lahar, and acidic aerosol formation at Mount Chiginagak volcano

Mount Chiginagak is a hydrothermally active volcano on the Alaska Peninsula, approximately 170 kilometers (100 miles) south-southwest of King Salmon. Sometime between November 2004 and May 2005, a 400-meter-wide ( 1,300-foot-wide), 100-meter-deep ( 300-foot-deep) crater lake developed in the formerly snow- and-ice-filled crater of the volcano (fig. 7). In early May 2005, an estimated 3 million cubic meters (106 million cubic feet) of sulfurous, clay-rich debris and acidic water exited the crater through tunnels in the base of a glacier that breaches the south crater rim (Schaefer and others, 2006). More than 27 kilometers (17 miles) downstream, the acidic waters of the flood reached approximately 1.3 meters ( $\sim$ feet) above current water levels and inundated an important salmon spawning drainage. The flow acidified Mother Goose Lake from surface to depth ( $\mathrm{pH}$ of 2.90 to 3.06) and prevented the annual salmon run in the King Salmon River. A release of caustic gas and acidic aerosols from the crater accompanied the flood, causing widespread vegetation damage along the flow path. 


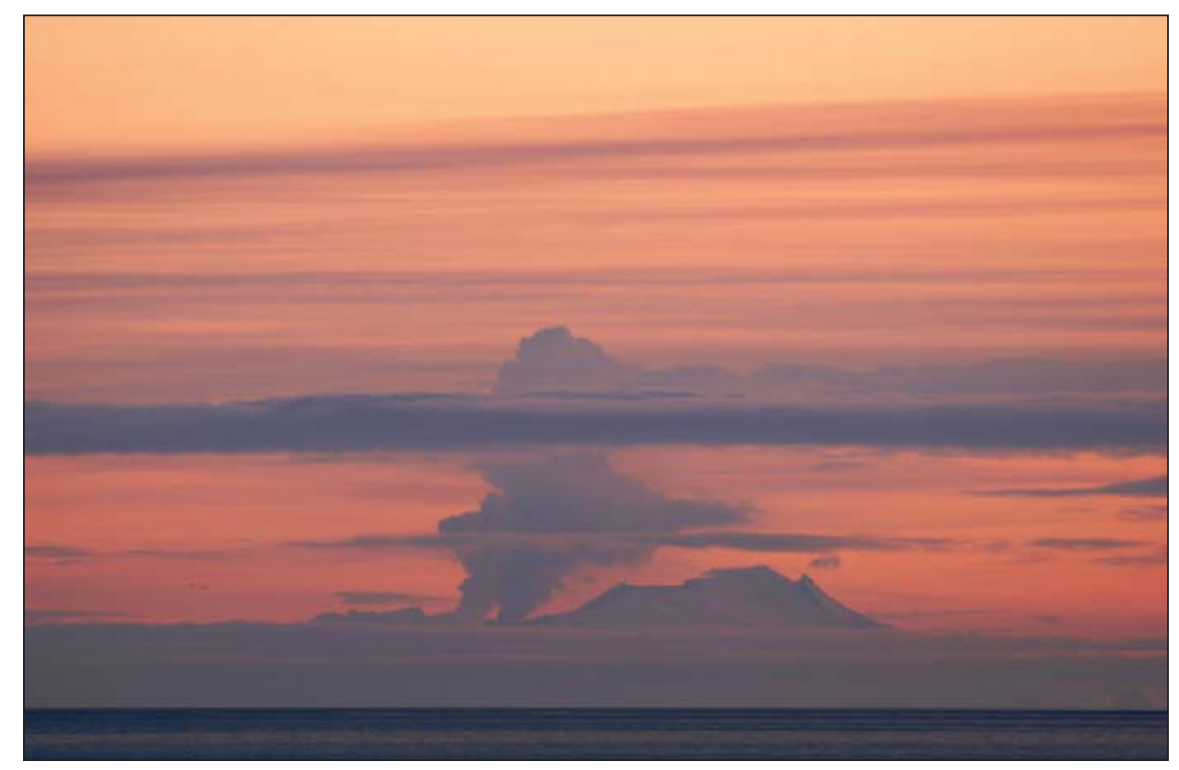

Figure 6. The September 17, 2006, eruption of Fourpeaked volcano as viewed from Homer, Alaska. Image courtesy of Lanny Simpson, Alaska High Mountain Images.

A DGGS-led interdisciplinary science team has been monitoring the status of the remaining crater-lake water that continues to flow into Mother Goose Lake. As of August 2007, the persistently high acidic conditions of Mother Goose Lake once again prevented the spawning run of salmon to this drainage. As part of a volcano-hazard assessment, the science team, in cooperation with Northern Arizona University lake core specialists, cored the bottom sediments of Mother Goose Lake with the goal of determining the recurrence interval for this type of acid flood from Chiginagak. Although Chiginagak volcano is not seismically instrumented, AVO monitors activity at the volcano with satellite imagery and with images sent to us from local pilots and residents in the area.

\section{AVO'S DATABASE-DRIVEN WEBSITE ALLOWS FOR EFFI- CIENT COMMUNICATION OF VOLCANO INFORMATION}

DGGS takes a lead role in providing timely and accurate information about volcanic unrest to both the public and emergency management officials. The DGGS-run AVO website (www.avo.alaska.edu) and its back-end database, GeoDIVA (Geological Database of Information on the Volcanoes of Alaska) is a world-class example of efficient information management related to volcanic activity. Highlights of both the internal and public websites, as well as GeoDIVA, are described below.

\section{AVO's internal website:}

The internal website has become the central location for managing information releases, images, field projects, and volcano observations. The database-driven applications AVO has developed for its internal site allow AVO personnel to use a web-based interface to efficiently distribute Volcanic Activity Notifications (VANs) to communicate changes in volcanic activity to government agencies, who then use the information to make decisions about governmental response to eruptions. This information is also simultaneously posted on AVO's public website, making it immediately available to the general public. The AVO internal website also displays complex near-real-time seismological and satellite data over the web for observatory staff, making distributed monitoring possible, instead of monitoring only from within the lab.

\section{AVO's public website:}

The public website provides both the general public and emergency managers with up-to-date information on volcanic activity, as well as background information on the volcanoes of Alaska including scientific literature, maps, eruption histories, and images. The AVO public website (www.avo.alaska.edu)

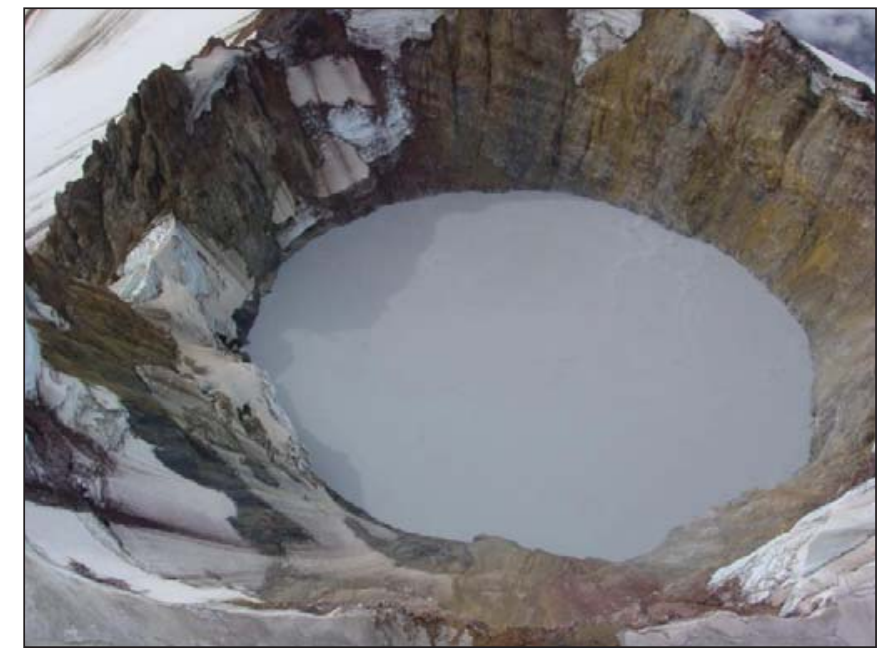

Figure 7. The crater lake at Chiginagak volcano. In 2005 this crater lake partially drained, sending a flood of acidic water into Mother Goose Lake and the King Salmon River. Photo by R. McGimsey, August 21, 2006. 
Active volcanoes of Kamchatka and the northern Kurile Islands

Ksudach

Zheltovsky

Iliyinsky

Koshelev

Kambalny

Alaid (11)

Elaid

Chikurachk

Fuss Peak

Karpinsky Group

Komarov

Gamchen

Kronotsky

Karymsky (6) Sheveluch (1)

Dzenzursky

Ushkovsky

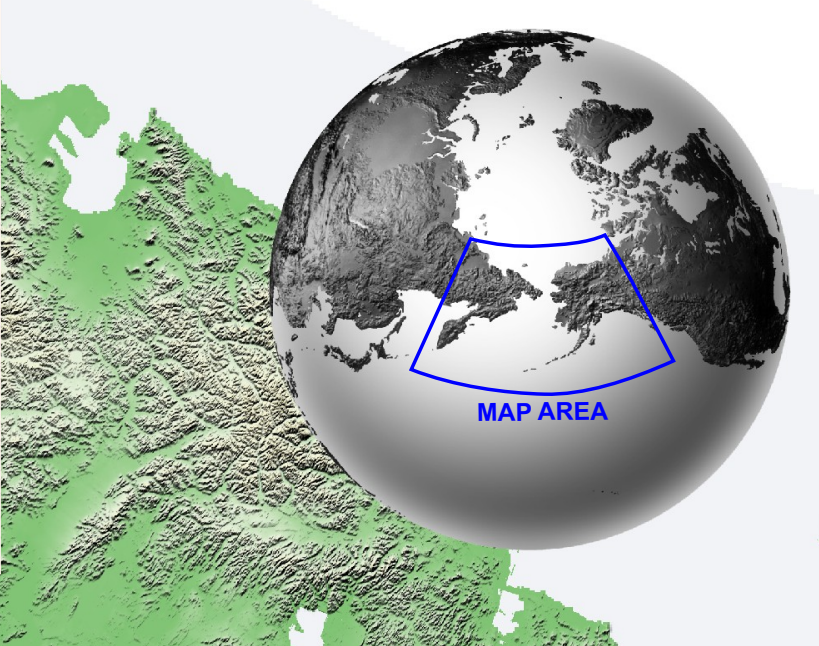

.

(11)

(1)

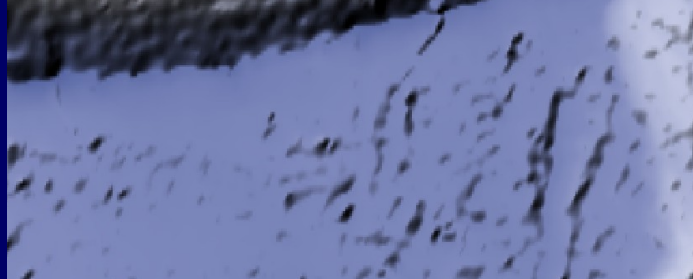

Krasheninnikov

Uzon

Kikhpinych

Bolshoi Semiachik

Maly Semiachik

Zhupanovsky Klyuchevskoy (2)

Koryaksky (7) Bezymianny (3)

Avachinsky (8) Plosky Tolbachik (4)

Ichinsky

New Tolbachik

Mutnovsky (10) Kizimen (5)

Numbers in parentheses refer to map locations below.

Shishaldin, 2004 +

Fisher, $1826+2$

Westdahl, 1992

Gilbert

象电。

Akutan, $1992+10$
Makushin, 1995?

Kiska, 1990

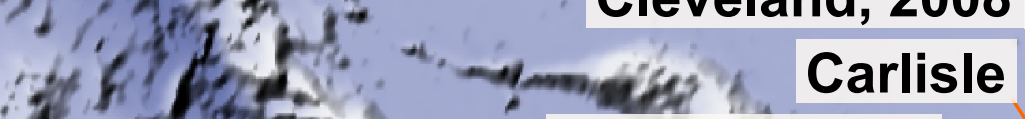

Yunaska, 1937

Little Sitkin, $\sim 1900$

Semisopochnoi, 1987

Gareloi, 1982

\section{Tanaga, 1914}

\section{Amukta, 1996}

Okmok, 1997 不

Bogoslof, 1992

Vsevidof, 1957

Kagamil

008

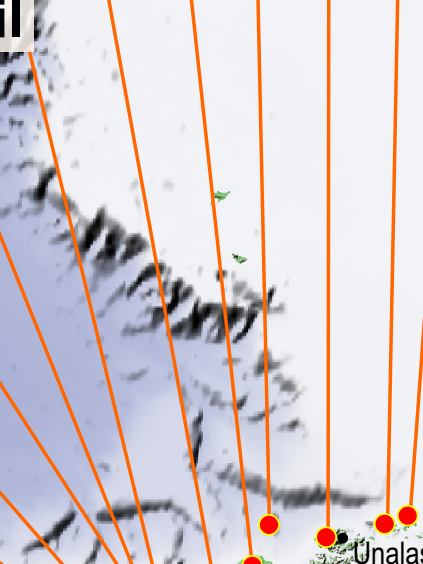

Q Adak Atka

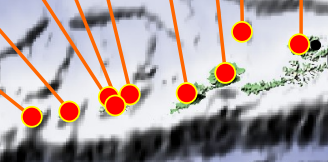

Cold
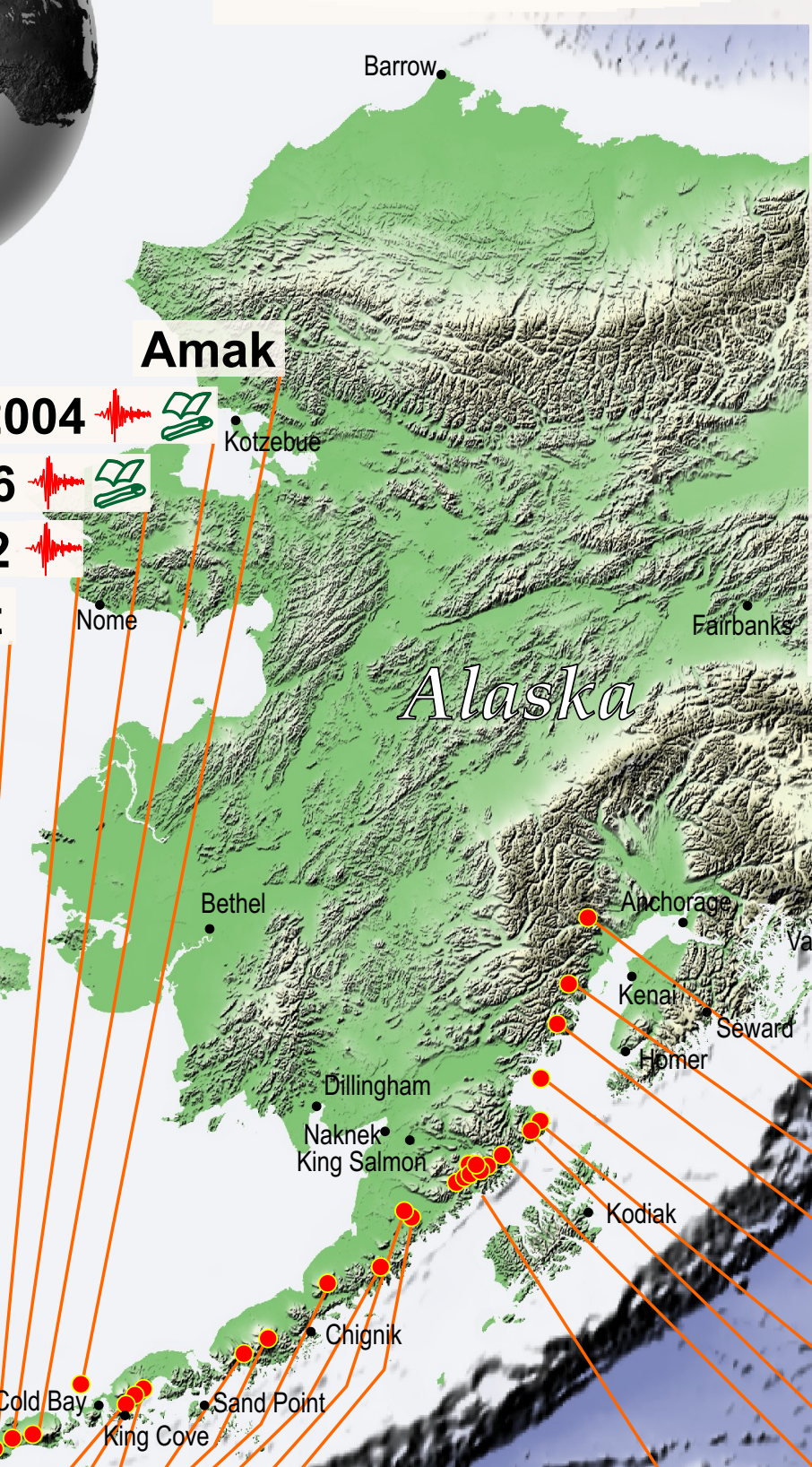

2008 year of most recent eruption

seismic network

不 continuous deformation network (GPS)

[-] telemetered remote camera (webcam)

updated geologic map and/or reports

51 active volcanoes are shown. There

are about 90 additional geologically young volcanoes.

All volcanoes are monitored several times each day using AVHRR and other satellites.

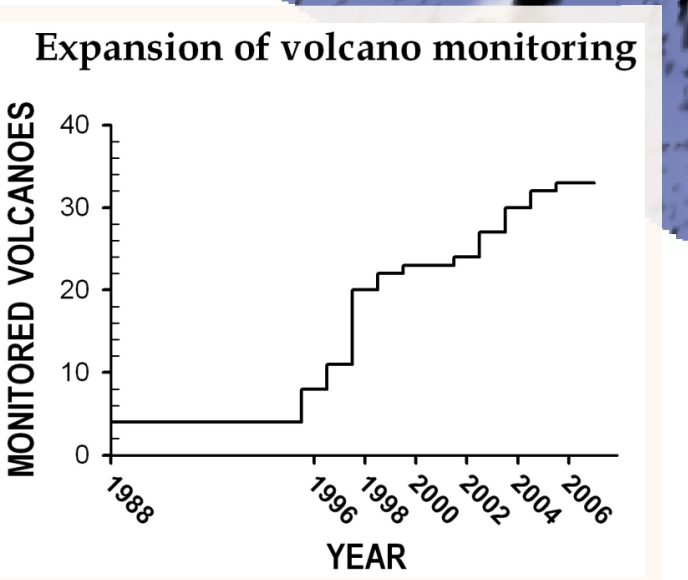

Kanaga, 1994

Great Sitkin, 1974

i. $y^{2}=$ Kasatochi

Kliuchef

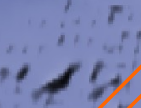

: Chiginagak

Ukinrek Maars, 1977

Aniakchak, 1931 .

Veniaminof, $2008+0$

Kupreanof

Korovin, 2006

Pavlof, $2007+0$

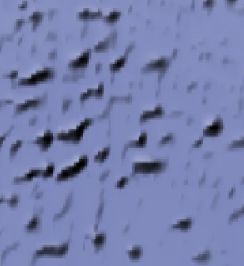

\section{Spurr, 1992}

Redoubt, 1990 标

lliamna 9

Augustine, 2006 不

Douglas

Fourpeaked 2006 Kukak

O Snowy

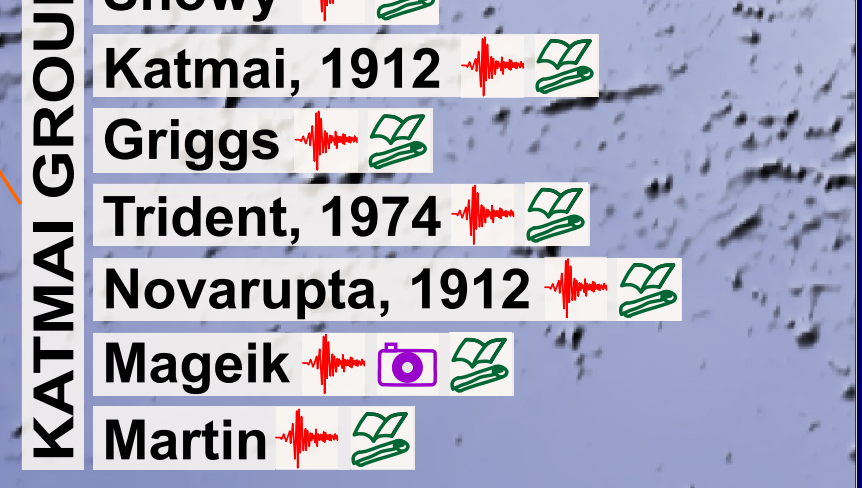


serves about 1,500,000 pages and approximately 300 gigabytes of data to well over 100,000 unique visitors per month. It is among the top ten USGS and USGS-affiliated websites in the country. DGGS was the original creator of the AVO website more than a decade ago, and continues to manage the site.

\begin{tabular}{|c|c|c|}
\hline Module & Status & Notes \\
\hline Bibliography & $\begin{array}{l}\text { Complete through } \\
2006\end{array}$ & $\begin{array}{l}\text { Will be updated yearly to } \\
\text { include new publications; } \\
\text { fully searchable. }\end{array}$ \\
\hline $\begin{array}{l}\text { Basic volcano } \\
\text { information }\end{array}$ & Complete & $\begin{array}{l}137 \text { major and } 197 \text { minor } \\
\text { volcanic features in } \\
\text { Alaska: } 54 \text { historically } \\
\text { active volcanoes (using } \\
\text { newly refined definition) }\end{array}$ \\
\hline $\begin{array}{l}\text { Eruption } \\
\text { history } \\
\text { information }\end{array}$ & $\begin{array}{l}\text { Complete through } \\
\text { mid } 2007\end{array}$ & $\begin{array}{l}\text { Information, actual text, } \\
\text { and references for more } \\
\text { than } 400 \text { historic } \\
\text { eruptions. }\end{array}$ \\
\hline Images & $\begin{array}{l}\text { Structure com- } \\
\text { plete-data } \\
\text { loading in } \\
\text { progress }\end{array}$ & $\begin{array}{l}\text { Currently contains more } \\
\text { than } 11,000 \text { pictures, } \\
\text { figures, and maps. } \\
\text { Images from previous } \\
\text { years, as well as current } \\
\text { photographs are being } \\
\text { added. }\end{array}$ \\
\hline $\begin{array}{l}\text { Sample } \\
\text { information }\end{array}$ & $\begin{array}{l}\text { Structure com- } \\
\text { plete-data } \\
\text { loading in } \\
\text { progress }\end{array}$ & $\begin{array}{l}\text { Currently contains } \\
\text { information for 3,000 } \\
\text { samples. Published } \\
\text { sample information, as } \\
\text { well as newly-collected } \\
\text { samples, are being added. }\end{array}$ \\
\hline Geochemistry & $\begin{array}{l}\text { Structure com- } \\
\text { plete-data } \\
\text { loading in } \\
\text { progress }\end{array}$ & $\begin{array}{l}\text { Geochemistry data } \\
\text { loaded for more than } \\
1,200 \text { samples ( } 45,000 \\
\text { records). Currently } \\
\text { adding analyses from } \\
\text { published sources. }\end{array}$ \\
\hline Petrology & $\begin{array}{l}\text { Structure com- } \\
\text { plete-data } \\
\text { generation and } \\
\text { loading in } \\
\text { progress }\end{array}$ & $\begin{array}{l}\text { Planned arc-wide thin } \\
\text { section images and } \\
\text { descriptions. } ~ 50 \\
\text { Augustine thin sections } \\
\text { with 1,000 point counts } \\
\text { complete. }\end{array}$ \\
\hline $\begin{array}{l}\text { Hand sample } \\
\text { storage }\end{array}$ & $\begin{array}{l}\text { Structure } \\
\text { complete }\end{array}$ & $\begin{array}{l}\text { Sample cataloging in } \\
\text { progress. Fairbanks } \\
\text { storage } 80 \% \text { complete. }\end{array}$ \\
\hline FieldDIVA & Beta phase & $\begin{array}{l}\text { Mini-GeoDIVA for field } \\
\text { use. (No field work done } \\
\text { in summer 2007.) }\end{array}$ \\
\hline GIS data & $\begin{array}{l}\text { Needs analysis } \\
\text { complete, } \\
\text { hardware/software } \\
\text { tools selected }\end{array}$ & $\begin{array}{l}\text { Currently constructing } \\
\text { database tables to hold } \\
\text { metadata and testing } \\
\text { hardware/software tools. }\end{array}$ \\
\hline Geochronology & Planned for FY08 & $\begin{array}{l}\text { Arc-wide age dates and } \\
\text { references, including } \\
\text { radiocarbon dates. }\end{array}$ \\
\hline
\end{tabular}

GeoDIVA: Geologic Database of Information on Volcanoes in Alaska

Tying it all together is GeoDIVA. GeoDIVA is the back-end database driving both the internal and public websites. The mission of GeoDIVA is to maintain complete, flexible, timely, and accurate geologic and geographic information on Pleistocene and younger Alaska volcanoes (those that have erupted in approximately the past 2 million years) for scientific investigation, crisis response, and public information in a dynamic, digital format. This information system is the most comprehensive, accurate, and up-to-date source of information on Alaska volcanoes available anywhere, online or in printed form. GeoDIVA is being developed in modules, which are released when finished, to streamline the delivery of information to the public (fig. 8). GeoDIVA uses the AVO website as its primary means of information dissemination.

\section{AVO IMPLEMENTS NEW VOLCANO HAZARD NOTIFICATIONS FOR VOLCANIC ACTIVITY}

As part of the National Volcano Early Warning System (NVEWS) initiative, the national volcano-monitoring community has been working to standardize official information-release formats. Two new update formats have resulted: VAN (Volcano Activity Notification), and VONA (Volcano Observatory Notice for Aviation). The intent of this change is to provide a clearer and more consistent statement of volcano hazard information. It is our hope that the more structured format of VAN and VONA will enable users to more quickly find the hazard content of most interest.

AVO is the test case for these formats, and DGGS has created the database structure and web application to create these information statements. As the other U.S. volcano observatories adopt this standard for releasing information, DGGS will serve as the primary contact for installing the application and database subsystem, as well as for future upgrades to the system.

A summary of AVO information products is listed below:

\section{VAN: Volcano Activity Notice}

Important announcement of volcanic activity or significant change in activity, aviation color code, or alert level.

VONA: Volcano Observatory Notice for Aviation Rigorously formatted message focusing on ash cloud hazards.

\section{DAILY STATUS REPORT:}

Short statement on the status of volcanoes at elevated aviation color code or alert level.

Figure 8. GeoDIVA module status. 


\section{WEEKLY SUMMARY:}

A recap of activity over the past week and current status of monitored volcanoes.

\section{INFORMATION STATEMENT:}

Expanded background information, hazard scenarios, announcements of new monitoring benchmarks, etc.

In addition to these information products, AVO staff make frequent calls directly to the Federal Aviation Administration, the National Weather Service, local U.S. military bases and airports, the Governor's Office of the State of Alaska, the Alaska Department of Emergency Services, airports and air carriers, and municipal and other civil authorities in the areas around the volcano.

\section{LOOKING TO THE FUTURE}

As AVO celebrates its 20-year anniversary this year, we are looking back on two decades of growth: growth in both instrumentation and data streams and growth in our knowledge of Alaska's volcanoes. We are now in a better position technologically to efficiently communicate volcano hazards to the public and emergency managers, and in a better position scientifically to better understand eruption processes and to predict eruptive behavior.

As more seismic, geochemical, geodetic, volcanic gas, and age data is collected and our understanding of Aleutian Arc magmatism grows, there will be a push for a more arc-wide synthesis of information. Answers to larger-scale questions, such as the following, can be attempted:

- What are the trends in magmatic production throughout the history of the arc?
- What do geochemical trends tell us about deep magma injection and mantle processes?

- Is there a pattern in seismic, gas release, and geodetic data that can help us predict volcanic eruptions?

The DGGS volcanology section staff look forward to pursuing answers to these questions with our continued participation in the Alaska Volcano Observatory. We will continue to excel in providing comprehensive information on Alaska volcanoes through our management of GeoDIVA and the AVO website. Our commitment to our objectives remains clear: we will represent the State of Alaska's interests and help mitigate risks to public safety and health by providing information on volcanic hazards as they affect human activity.

\section{REFERENCES}

Brantley, S.R., 1990, The eruption of Redoubt volcano, Alaska, December 14, 1989-August 31, 1990: U.S. Geological Survey Circular 1061, 33 p.

Casadevall, T.J., 1994, Volcanic ash and aviation safety: Proceedings of the first international symposium on volcanic ash and aviation safetey. U.S. Geological Survey Bulletin 2047, 450 p.

Gardner, C.A., and Guffanti, M.C., 2006, U.S. Geological Survey’s Alert Notification System for Volcanic Activity: U.S. Geological Survey Fact Sheet 2006-3139, 4 p.

Power, J.A., Nye, C.J., Coombs, M.L., Wessels, R.L., Cervelli, P.F., Dehn, J., Wallace, K.L., Freymueller, J.T., and Doukas, M.P., 2006, The reawakening of Alaska's Augustine Volcano: Eos, v. 87, n. 37, p. 373, 377.

Schaefer, J.R., Scott, W.E., McGimsey, R.G., and Jorgenson, Janet, 2006, The 2005 crater lake formation, lahar, acidic flood, and caustic aerosol and gas release from Chiginagak Volcano, Alaska [abs.]: Geological Society of America - Abstracts with Programs, v. 38 , n. 5 , p. 29.

\section{Dear Readers:}

Hello again, and thanks for picking up our newsletter and getting up to speed on the latest news at DGGS. As always, we are up to our Brunton compasses in map compilations, spreadsheets of analyses from last summer's samples, and logistical plans for the coming field season. I encourage you to visit our website and download our latest annual report (http://www.dggs.dnr.state.ak.us/webpubs/dggs/ar/text/ar2007.PDF) for summaries of all the projects our staff are diligently working on.

I also want to thank Janet Schaefer, geologist with the Volcanology Section, for providing the excellent article on the volcanoes in Alaska and the activities of the Alaska Volcano Observatory. That program, operated in partnership with the U.S. Geological Survey and the University of Alaska Fairbanks, is one of the flagship programs here at the State Survey and we are very proud to be an active member. The federal support that has made this program a reality has provided an incredible service to the public, the aviation sector, and many other industries operating in the Cook Inlet and Alaska Peninsula region. Additionally, this group has helped to significantly advance the science of volcanology at a local and international scale.

One "geologic" issue that is worth discussing since it will likely be affecting us all in the coming years is Global Climate Change. Who could have envisioned that such relatively benign words (to a geologist, that is) would strike such fear in the hearts of so many people? Those of us who are intrigued by the physical history of the earth have spent our careers studying the rock record and deciphering the results of dramatic variation in both climate and sea 
level through geologic time. As was pointed out so aptly by Kirk Johnson, Director of the Denver Museum of Natural History, "Hippos in London and alligators in Stavanger are not really anomalies, but more the norm when one considers the whole picture of earth's history." In fact, climate observations being made today are not necessarily surprising to a geologist thinking in terms of geologic time.

Nevertheless, a vast majority of the public do not concern themselves with geologic time, nor with the fact that the polar regions have been ice-free much longer during earth's history that they have had ice caps. The voting public is much more interested in recent trends in temperature and how this will all play out within their lifetime. More importantly, the general public is fearful ("Be Very Worried," TIME magazine, April 2006) of how the currently forecasted change, and attempted mitigation of that change, will affect their lifestyles, financial investments, and the lives of their children. Those are important things to worry about!

Policy makers at both the federal and state levels are busy working up bills aimed at reducing our greenhouse gas emissions and encouraging a switch of energy sources to those that emit less (or no) CO2. Unfortunately this is not a simple situation that can easily be dealt with by hasty legislation.

Take a look at a few interesting points to ponder:

- There are more than 6 billion humans currently alive on the planet, with a projected 9 billion people to be alive at some point during our children's lifetimes (by 2050).

- Human expansion and activity has had a dramatic effect on surficial and atmospheric processes on earth, and will continue to do so with increasing intensity.

- The amount of increased energy production that will be needed to sustain a 30 percent increase in population in the next 45 years (assuming the current distribution of lifestyles) is commensurate with the energy development that has occurred over the last 150 years.

- There were 1.5 billion people on earth, and huge herds of wild buffalo roaming the central U.S. grasslands a mere 150 years ago.

- The development and production of sustainable energy sources at the scales needed to sustain current lifestyles is difficult to comprehend without significant changes in technology.

- All production of energy involves some form of action/reaction, and if produced in large quantities, will result in some form of environmental degradation.

- The United States has a little more than 4 percent of global population yet consumes 25 percent of the world's energy production and has, until recently, enjoyed cheap and abundant energy that has fueled and sustained a robust U.S. economy.

- CO2 emissions from human activity, as well as natural emissions, are clearly contributing to global temperature rise, but are not the whole story.

- Global temperatures have changed dramatically without anthropogenic influx of CO2.

- If all countries would have ratified the Kyoto Protocol, and were able to meet the reduction timetables, the ultimate predicted 2100 global temperature would be offset by 5 years, to 2105 .

- The United Nations predicts that sea level will rise about 1 foot by 2100.

- Global sea level has risen about 1 foot since 1860.

- Glaciers have been continually receding since the Little Ice Age in the late 1800s.

- Rates of glacial retreat have accelerated in recent decades.

- Global average temperature has risen by about $1.4^{\circ} \mathrm{C}$ since 1900 . The IPPC models predict that it will take another 50 years to see the same rise.

- Temperatures will not fluctuate equally across the globe.

- There have been major floods and erosive events happening every year, all over the globe, during all global climate scenarios.

- Flooding and erosion are disasters only when we build infrastructure or allow development in hazard-prone areas (i.e., floodplains are called floodplains for a reason).

- The northern 'tree-line' has been moving north since the last ice age, and likewise has moved both north and south dramatically over time.

The bottom line: There are no easy answers to the questions being raised. Unfortunately, suggestions of alternate hypotheses for any of the polarized viewpoints are often met with vigorous denial and debate, and at times even name-calling. I believe it is critical that we all try to understand what the facts are, realize that dramatic environmental change has been ubiquitous throughout earth's history, think critically about what should be considered solvable problems and define the root of those problems, think long-term into both the future and the past, and attempt to 
work together on finding realistic solutions or responses to the impacts human activities are having on the planet we call home. Finally, we must never forget the resilience and unpredictability of life, nor that of the planet earth.

Bob Swenson

Alaska State Geologist

\section{SOURCES OF INFORMATION:}

U.S. Census Bureau, Global Population Profile: 2002, Report WP/02

The National Academies: Understanding and Responding to Climate Change

Pew Center on Global Climate Change: Climate Change 101

Energy Information Administration: Energy Statistics from the U.S. Government

U.S. Department of Energy, Office of Fossil Energy

Bjorn Lomborg, 2007, Cool it, the Skeptical Environmentalist’s Guide to Global Warming: New York, Alfred Knopf publisher, 253 p.

Great Plains Bison Association

\section{NEW DGGS PUBLICATIONS}

\section{ANNUAL REPORTS}

AR 2007. Alaska Division of Geological \& Geophysical Surveys Annual Report, by DGGS Staff, 2008, 69 p. Free

\section{GEOPHYSICAL MAPS \& REPORTS}

GB 8. A guide to the late Quaternary history of northern and western Kenai Peninsula, Alaska, by Reger, R.D., Sturmann, A.G., Berg, E.E., and Burns, P.A.C., 2008, 112 p., 6 sheets, scale 1:63,360. $\$ 25$

GPR 2007-1. Line, grid, and vector data, and plot files for the airborne geophysical survey of part of the Bonnifield mining district, Interior Alaska, by Burns, L.E., Fugro Airborne Surveys Corp., and Stevens Exploration Management Corp., 2007, 1 DVD. \$15

GPR 2007-1-1A. Total magnetic field of part of the Bonnifield mining district, Interior Alaska, by Burns, L.E., Fugro Airborne Surveys Corp., and Stevens Exploration Management Corp., 2007, 2 sheets, scale 1:63,360. Topography included. \$26

GPR 2007-1-1B. Total magnetic field of part of the Bonnifield mining district, Interior Alaska, by Burns, L.E., Fugro Airborne Surveys Corp., and Stevens Exploration Management Corp., 2007, 2 sheets, scale 1:63,360. Magnetic data contours included. \$26

GPR 2007-1-1C. First vertical derivative of the total magnetic field of part of the Bonnifield mining district, Interior Alaska, by Burns, L.E., Fugro Airborne Surveys Corp., and Stevens Exploration Management Corp., 2007, 2 sheets, scale 1:63,360. Topography included. \$26

GPR 2007-1-2A. 56,000 Hz coplanar apparent resistivity of part of the Bonnifield mining district, Interior Alaska, by Burns, L.E., Fugro Airborne Surveys Corp., and Stevens Exploration Management Corp., 2007, 2 sheets, scale 1:63,360. Topography included. \$26

GPR 2007-1-2B. 56,000 Hz coplanar apparent resistivity of part of the Bonnifield mining district, Interior Alaska, by Burns, L.E., Fugro Airborne Surveys Corp., and Stevens Exploration Management Corp., 2007, 2 sheets, scale 1:63,360. 56,000 Hz resistivity data contours included. \$26
GPR 2007-1-3A. $7200 \mathrm{~Hz}$ coplanar apparent resistivity of part of the Bonnifield mining district, Interior Alaska, by Burns, L.E., Fugro Airborne Surveys Corp., and Stevens Exploration Management Corp., 2007, 2 sheets, scale 1:63,360. Topography included. \$26

GPR 2007-1-3B. $7200 \mathrm{~Hz}$ coplanar apparent resistivity of part of the Bonnifield mining district, Interior Alaska, by Burns, L.E., Fugro Airborne Surveys Corp., and Stevens Exploration Management Corp., 2007, 2 sheets, scale 1:63,360. $7200 \mathrm{~Hz}$ resistivity data contours included. \$26

GPR 2007-1-4A. $900 \mathrm{~Hz}$ coplanar apparent resistivity of part of the Bonnifield mining district, Interior Alaska, by Burns, L.E., Fugro Airborne Surveys Corp., and Stevens Exploration Management Corp., 2007, 2 sheets, scale 1:63,360. Topography included. \$26 GPR 2007-1-4B. $900 \mathrm{~Hz}$ coplanar apparent resistivity of part of the Bonnifield mining district, Interior Alaska, by Burns, L.E., Fugro Airborne Surveys Corp., and Stevens Exploration Management Corp., 2007, 2 sheets, scale 1:63,360. $900 \mathrm{~Hz}$ resistivity data contours included. \$26

GPR 2008-1. Line, grid, and vector data, plot files, and descriptive project report for the airborne geophysical survey of part of the western Fortymile mining district, east-central Alaska, by Burns, L.E., U.S. Bureau of Land Management, Fugro Airborne Surveys Corp., and Stevens Exploration Management Corp., 2008, 1 DVD. $\$ 15$

GPR 2008-1-1A. Total magnetic field of part of the western Fortymile mining district, east-central Alaska; topography included, by Burns, L.E., U.S. Bureau of Land Management, Fugro Airborne Surveys Corp., and Stevens Exploration Management Corp., 2008, 1 sheet, scale 1:63,360. \$13

GPR 2008-1-1B. Total magnetic field of part of the western Fortymile mining district, east-central Alaska; magnetic data contours included, by Burns, L.E., U.S. Bureau of Land Management, Stevens Exploration Management Corp., and Fugro Airborne Surveys Corp., 2008, 1 sheet, scale 1:63,360. \$13

GPR 2008-1-1C. First vertical derivative of the total magnetic field of part of the western Fortymile mining district, east-central Alaska, by Burns, L.E., U.S. Bureau of Land Management, Stevens Exploration Management Corp., and Fugro Airborne Surveys Corp., 2008, 1 sheet, scale 1:63,360. \$13 
GPR 2008-1-2A. 56,000 Hz coplanar apparent resistivity of part of the western Fortymile mining district, east-central Alaska; topography included, by Burns, L.E., U.S. Bureau of Land Management, Stevens Exploration Management Corp., and Fugro Airborne Surveys Corp., 2008, 1 sheet, scale 1:63,360. \$13

GPR 2008-1-2B. 56,000 Hz coplanar apparent resistivity of part of the western Fortymile mining district, east-central Alaska; 56,000 $\mathrm{Hz}$ resistivity data contours included, by Burns, L.E., U.S. Bureau of Land Management, Stevens Exploration Management Corp., and Fugro Airborne Surveys Corp., 2008, 1 sheet, scale $1: 63,360 . \$ 13$

GPR 2008-1-3A. $7200 \mathrm{~Hz}$ coplanar apparent resistivity of part of the western Fortymile mining district, east-central Alaska; topography included, by Burns, L.E., U.S. Bureau of Land Management, Stevens Exploration Management Corp., and Fugro Airborne Surveys Corp., 2008, 1 sheet, scale 1:63,360. \$13

GPR 2008-1-3B. $7200 \mathrm{~Hz}$ coplanar apparent resistivity of part of the western Fortymile mining district, east-central Alaska; $7200 \mathrm{~Hz}$ resistivity data contours included, by Burns, L.E., U.S. Bureau of Land Management, Stevens Exploration Management Corp., and Fugro Airborne Surveys Corp., 2008, 1 sheet, scale 1:63,360. $\$ 13$

GPR 2008-1-4A. $900 \mathrm{~Hz}$ coplanar apparent resistivity of part of the western Fortymile mining district, east-central Alaska; topography included, by Burns, L.E., U.S. Bureau of Land Management, Stevens Exploration Management Corp., and Fugro Airborne Surveys Corp., 2008, 1 sheet, scale 1:63,360. \$13

GPR 2008-1-4B. $900 \mathrm{~Hz}$ coplanar apparent resistivity of part of the western Fortymile mining district, east-central Alaska; $900 \mathrm{~Hz}$ resistivity data contours included, by Burns, L.E., U.S. Bureau of Land Management, Stevens Exploration Management Corp., and Fugro Airborne Surveys Corp., 2008, 1 sheet, scale 1:63,360. $\$ 13$

GPR 2008-2. Preliminary final version of part of the airborne geophysical data from the Styx River Survey, southcentral Alaska: parts of Lime Hills and Tyonek quadrangles, by Burns, L.E., Fugro Airborne Surveys Corp., Stevens Exploration Management Corp., and Anglo American Exploration (USA), Inc., 2008, 5 sheets, scale 1:63,360, 1 CD. GPR 2008-2 contains geophysical data produced from airborne surveys conducted in 2007 for the eastern part of the Styx River survey area, southcentral Alaska. The data have been processed to the final stage; however, when the data are merged with data for the remaining area, minor changes to these maps and data might be necessary. The remaining survey area data will be acquired, processed, merged with this data, and released as GPR 2008-3. \$10

\section{GUIDEBOOK}

GB 8. A guide to the late Quaternary history of northern and western Kenai Peninsula, Alaska, by Reger, R.D., Sturmann, A.G., Berg, E.E., and Burns, P.A.C., 2008, 112 p., 6 sheets, scale 1:63,360. $\$ 25$

\section{INFORMATION CIRCULAR}

IC 54. Alaska’s Mineral Industry 2006: A summary, by Szumigala, D.J., and Hughes, R.A., 2007, 20 p. Free

\section{NEWSLETTER}

NL 2007-1. Alaska GeoSurvey News, by DGGS Staff, 2007, 6 p. Free

\section{PRELIMINARY INTERPRETIVE REPORT}

PIR 2007-1. Geologic map of the Siksikpuk River area, Chandler Lake Quadrangle, Alaska, by Peapples, P.R., Wallace, W.K., Wartes, M.A., Swenson, R.F., Mull, C.G., Dumoulin, J.A., Harris, E.E., Finzel, E.S., Reifenstuhl, R.R., and Loveland, A.M., 2007, 1 sheet, scale 1:63,360. $\$ 13$

PIR 2007-2. Brookian sequence stratigraphic correlations, Umiat Field to Milne Point Field, west-central North Slope, Alaska, by Decker, P.L., 2007, 19 p., 1 sheet. \$15

\section{RAW-DATA FILES}

RDF 2007-1. Trace element geochemical data from reanalysis of stream-sediment samples collected in 1981 from the Fairbanks mining district, Alaska, by Jozwik, Diana, 2007, 170 p. \$17

RDF 2007-2. Data tables related to geology and gold mineralization in the Richardson district, east-central Alaska, by Graham, G.E., and Jozwik, Diana, 2007, 32 p. \$3

RDF 2007-3. Outcrop sample results from mercury injection capillary pressure analyses, Bristol Bay, Alaska Peninsula, by Loveland, A.M., Reifenstuhl, R.R., Gillis, R.J., and Decker, P.L., 2007, 11 p. $\$ 2$

RDF 2007-4. Major-oxide, minor-oxide, trace-element, geochemical, and non-carbonate carbon data from rocks collected in the Solomon and Nome quadrangles, Seward Peninsula, Alaska in 2006, by Werdon, M.B., Newberry, R.J., Szumigala, D.J., Freeman, L.K., and Athey, J.E., 2007, 49 p. \$5

RDF 2008-1 v. 1.0.1. Major-oxide, minor-oxide, and trace-element geochemical data from rocks and stream sediments collected in the northern Fairbanks mining district, Circle Quadrangle, Alaska in 2007, by Athey, J.E., Freeman, L.K., Werdon, M.B., Szumigala, D.J., Lessard, R.R., Newberry, R.J., Hansen, S.E., and Jing, L., 2008, 41 p. $\$ 5$

RDF 2008-2. Major-oxide, minor-oxide, trace-element and geochemical data from rocks collected in the Alaska Highway corridor Mount Hayes Quadrangle, Alaska in 2006 and 2007, by Solie, D.N., Werdon, M.B., Newberry, R.J., Freeman, L.K., and Lessard, R.R., 2008, 23 p. $\$ 2.50$

\section{REPORT OF INVESTIGATIONS}

RI 2007-1. Sequence stratigraphy and geochemistry of the upper Lower through Upper Triassic of Northern Alaska: Implications for paleoredox history, source rock accumulation, and paleoceanography, by Kelly, L.N., Whalen, M.T., McRoberts, C.A., Hopkin, E., and Tomsich, C.S., 2007, 50 p. \$5

RI 2007-2. Petrographic study of 50 samples from the Tertiary sandstone of Cook Inlet, Alaska: potential tight gas reservoirs, by Hickey, J.J., Wilson, M.D., and Reifenstuhl, R.R., 2007, 64 p. $\$ 7$

\section{SPECIAL REPORTS}

SR 61. Alaska’s Mineral Industry 2006, by Szumigala, D.J., and Hughes, R.A., 2007, 83 p. Free 


\section{NEWON THE DGGS WEBSITE!}

The Division of Geological \& Geophysical Surveys recently improved its website (www.dggs. dnr.state.ak.us) with RSS Feed, a unique new web tool for finding and delivering information from our site. This new tool provides up-to-the-minute news and updates. Click on the orange button $\mathbb{A}$ shown on our pages and your web browser will display the contents of the DGGS news feed page. You can then "bookmark" this page by subscribing to the RSS feed.

\section{WHAT IS RSS?}

RSS is a relatively new on-line technique that allows you to read news and updates from multiple web sites all from one place, typically with a web browser, feed reader program, or even an iPod.

\section{HOW CAN I SUBSCRIBE TO THE DGGS NEWS RSS FEED?}

There are two common ways to subscribe to our RSS feed: (1) a web browser that supports RSS or (2) a stand-alone RSS feed reader. News readers are small programs that check RSS feeds from websites you choose and let you read any articles that recently have been added.

\section{CAN I GET NOTICES BY E-MALL?}

Yes! On the bottom right corner is a box in which you can enter your e-mail address. Once you click on the "Subscribe" button, you will be subscribed to our e-mail notification service and all of the news headlines will be sent to you immediately upon their posting. You may unsubscribe at any time by following the instructions at the bottom of any e-mail sent to you.

\section{ORDERING INFORMATION}

For each publication ordered, include both the publication title and number. Mail orders are payable in advance. Make check or money order in U.S. currency and payable to the State of Alaska. Credit cards are accepted. Telephone orders are accepted by the Fairbanks office between 8 a.m. and 4:30 p.m. Alaska time. Fax and email requests are accepted any time; these orders will be invoiced. If you would like to leave your order on voice mail, this can also be done 24 hours a day and you will be invoiced.

Please send address corrections to: Newsletter

Alaska Division of Geological \& Geophysical Surveys 3354 College Rd., Fairbanks, AK 99709-3707

(907) 451-5020 (907)451-5050 fax email: dggsnews@alaska.gov

\section{SHIPPING \& HANDLING}

Shipping charge will be the actual cost of postage and will be added to the total amount due. Please e-mail or call for an exact amount.

\section{WHERE TO ORDER}

Publications of the Division of Geological \& Geophysical Surveys are available over the counter, by mail, phone, fax, or email from the DGGS Fairbanks office:

ATTN: Geologic Communications Section-Publication Sales

Alaska Division of Geological \& Geophysical Surveys, 3354 College Rd.

Fairbanks, AK 99709-3703

(907) 451-5020 Fax (907) 451-5050

Email: dggspubs@alaska.gov

Prices of DGGS publications are subject to change. Increases in costs make it necessary to raise the selling prices of many publications offered. It is not feasible for DGGS to change the prices stated in previous announcements and publications in stock, so the prices charged may differ from the prices in the announcements and publications. Overpayments of $\$ 2$ or less will not be refunded. 


\section{STATE OF ALASKA \\ DEPARTMENT OF NATURAL RESOURCES \\ DIVISION OF GEOLOGICAL \& GEOPHYSICAL SURVEYS}

Mail order to:

Alaska Division of Geological \& Geophysical Surveys

Attn: Geologic Communications Section

E-mail: dggspubs@alaska.gov

3354 College Rd.

http://www.dggs.dnr.state.ak.us

(907) 451-5020

Fairbanks, Alaska 99709-3707

\begin{tabular}{|c|c|c|}
\hline Report Number & Report Name & Price \\
\hline & & \\
\hline & & \\
\hline & & \\
\hline & & \\
\hline & & \\
\hline & & \\
\hline & & \\
\hline & & \\
\hline & & \\
\hline & & \\
\hline & & \\
\hline & & \\
\hline & & \\
\hline & & \\
\hline & & \\
\hline & & \\
\hline
\end{tabular}

POSTAGE: Shipping charge will be the actual cost of postage and will be added to the total amount due. You may e-mail or call for an exact amount.

\section{Ship publication(s) to:}

Name

Organization

Address

City, State

Zip

Payment must accompany your order. Make check or money order payable to STATE OF ALASKA. We accept Visa and MasterCard. For payment by credit card, please contact our office at (907) 451-5020. 